\title{
On a Third Cold War
}

Sergei A. Karaganov

\author{
Sergei A. Karaganov, DSc (History) \\ Council on Foreign and Defense Policy, Russia \\ Honorary Chairman of the Presidium; \\ National Research University-Higher School of Economics, Moscow, Russia \\ Faculty of World Economy and International Affairs \\ Dean and Academic Supervisor \\ SPIN RSCI: $6020-9539$ \\ ORCID: 0000-0003-1473-6249 \\ ResearcherID: K-6426-2015 \\ Scopus AuthorID: 26025142400 \\ Email: skaraganov@hse.ru \\ Address: Office 103, 17, Bldg.1 Malaya Ordynka Str., Moscow 119017, Russia \\ DOI: $10.31278 / 1810-6374-2021-19-3-102-115$
}

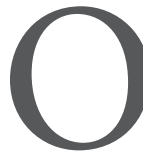

ver the last six months, most commentators have finally stopped saying that the relationship between Russia and the United States is "at its worst since the end of the Cold War" and begun recognizing the obvious: a new Cold War is unfolding. The current state of affairs is increasingly reminiscent of the 1950s, naturally, with necessary adjustments for the new international situation. I believe that Russia can get out of the current aggravation as a winner. It only needs to make the right choice in its domestic and foreign policies and, most importantly, avoid getting involved in a big war, which may turn into a global thermonuclear and cyberspace Armageddon.

So far we are in a winning position in the new round of the Cold War, but we can lose again. In fact, throughout history, Russia has many times "wrested a defeat out of the hands of victory." 


\section{THE FIRST TWO ROUNDS}

Millions of pages have been written about the history and theory of the Cold War. I will give you one more interpretation. The Cold War is one of the types of international competition for resources (territory, population, and economic potential per se) that has accompanied humanity throughout its history. And this rivalry will continue unless human nature changes mentally or physically. This struggle, caused mainly by geoeconomic and geopolitical reasons, always had a pronounced ideological component that often came to the fore.

The beginning of what we now call the Cold War essentially dates back to the October Revolution of 1917. At that time the geoeconomic and geopolitical elements were much stronger than ever before and were combined with communist ideology that totally rejected private property. The example of Soviet Russia-the USSR - showed power holders around the world that economic assets such as land, factories, or finances could be seized from their owners, which was seen as a huge threat.

Communist ideology, with its emphasis on justice, equality of people, including genders, and the freedom of nations, was very attractive. The West tried to crush communist Russia during the civil war and refused to recognize it after it. The situation changed slightly due to the Great Depression when technologies and specialists came to the Soviet Union. But attempts to strangle the country continued. German monopolistic capital, as it was commonly called, supported Hitler against the communists. Then the West's ruling elite persistently pushed him against the USSR. There was a sincere ideological component in that struggle: communists denied not only private property, but also some of the basic human values, particularly faith, the family, and history.

That Cold War ended with World War II, although it was not its main cause. The world war was unleashed, initially within the West, by humiliated and despoiled Germany with its monstrous ideology. The war was fought for resources, although it was disguised with ideological slogans - the struggle against Communism, rotten democracies, and so on. So, the first Cold War was primarily ideological, then geoeconomic, and finally geopolitical. 
The second Cold War, more familiar to us, was without a doubt also fought for control over resources as well, but to a lesser extent on the part of the USSR. We sought to ensure security, and there were also the remains of communist internationalism in the form of support for national liberation movements rather than the world socialist revolution. The Soviet Union waged the Cold War more for geostrategic reasons and to a lesser extent for ideological ones. The West justified the competition by the need to fight "godless communism" and protect democracy, but the main driving motives were geoeconomic and geopolitical, that is, preserving the shrinking area of dominance and control over resources. Gradually, as the arms race got underway, geostrategic motives-the desire to avoid a nuclear Armageddon-began to prevail on both sides.

The late1940s and the 1950s are generally considered the Cold War's climax. The intensity of hostile, de facto war-like propaganda and the witch hunt in those days are similar to what we see today. That fierce clash would almost certainly have led to World War III if Almighty, out of pity for humanity, had not given it nuclear weapons through Sakharov, Kurchatov, Oppenheimer, Fermi and their colleagues, thus making a war theoretically unthinkable, leading to the self-destruction of all.

As we know, the Soviet Union lost the second round of the Cold War. In the 1960s the communist leadership proved unable to abandon the socialist (non-market) economic system, which increasingly demonstrated its inefficiency (Kosygin's reform plan was rejected). Obsessed with security and the remains of communist ideology that began to wilt, we missed our Deng Xiaoping moment. This was largely the main reason why communist ideology, which underpinned the Soviet statehood, began to rapidly lose traction in society as it failed to meet people's basic needs. Besides, the USSR invested in defense beyond all reasonable measure.

The situation was aggravated by a quarrel with China, which by the end of the 1960s had put the Soviet Union in a situation where it had to mobilize resources in order to be ready to fight on two fronts, thus further militarizing its economy.

Subsidizing the ideology-based expansion in the Third World and keeping the socialist camp afloat required more and more money. 
The allies were costly, but mostly unreliable. The generous ideology of communist internationalism created a situation where Russia (within its current borders) was forced to pump huge resources into the other Soviet republics (as is known, Ukraine received the most in total and Georgia, in per capita terms).

No one has ever been able and may never be able to calculate how much exactly the USSR (Russia) paid for maintaining the colossal military machine and subsidizing the Soviet republics, socialist countries and the states of social orientation in the Third Worldroughly, about 35-40 percent of GNP, that is, six to seven times more than defense and foreign policy cost now.

The costly invasion of Afghanistan that claimed thousands of Soviet lives finished off the country. When I studied its motives, I came to the conclusion that there were no economic reasons among them, but there was an obsession with security, a sense of encirclement and threats from all sides-and all this at the peak of Soviet military strength. Ideological factors played an insignificant role of a "wrapper."

As a result of the collapse of the USSR and the socialist camp and China's transition to a market economy, the West received enormous new resources-markets and hundreds of millions of cheap workersand restored its dominance in the global political, economic, and cultural spheres. Now the West, which had siphoned off world GNP for about four or five centuries through direct colonial robbery, could do it in a more refined way.

The dominance, gained by Europe and the West some five hundred years ago was primarily based on military superiority, faltered when Soviet Russia fell out of the system. But it started to burst at the seams in earnest in the 1950s-1960s when the Soviet Union and then China created their own nuclear weapons, thereby depriving the Western supremacy of its main support-military power. The West began to lose-first in the Vietnam War, and then faced with an oil embargo imposed by the emboldened Arabs.

In the 1990s, the West seemed to have regained its dominance when an internally weak Russia had lost the ability to deter it effectively. The 
West fancied an ideological victory, primarily in liberal values-human rights, the rule of law, democracy (interpreted rather modestly at that time). They looked particularly attractive due to a much better comfort and quality of life in the West compared to the meagre living standards of real socialism.

The military and security segments of the American elite claimed that the Soviets had surrendered due to the threat of a new round of the arms race. But I know that it was not so. By the time of the "fake" threat of star wars, the USSR had already de facto lost due to the erosion of the underlying communist idea and ineffective economy further exacerbated by imperial overreach. If it had not been for the latter, the USSR would have lasted longer and the end would perhaps have not been so painful.

In the panic of defeat (the USSR) and in the euphoria of the seemingly final victory (the West), both sides began to make strategic mistakes.

The USSR, and then Russia, deprived intellectually for many decades of communist unanimity, proceeded with a suicidal political liberalization before and simultaneously with market reforms which can be effective only under authoritarian rule, as was basically the case almost everywhere during the modernization and active development of capitalism. The relative exception is the United States: for all external similarity to Europe, the U.S. is a unique civilization born as a republic, which has never been seriously threatened by anyone.

Another mistake that stemmed from the same decades-long intellectual tunnel thinking was the widespread belief that "the West will help us." It is clear now that it did not.

So, the second Cold War was primarily geostrategic, then geopolitical and geoeconomic on the part of the West. The ideological factor was the fourth, often used to cover up and justify the first three. Its role was bigger in the 1940s-1950s, but in the 1960s it began to noticeably fade into the background, becoming more of an instrument (human rights) than a driving force. And yet, most analysts believe that ideology was the main motivator. But I do not think so.

After the end of the second round of the Cold War, Russia was pushed aside and subjected to unjust, but not openly hostile, treatment. 
It was considered hopelessly weakened, and some thought it could be integrated on Western conditions so as to gain control of its most important resources-oil and gas. But these hopes crashed down after the Yukos case. Some observers argue that the Cold War has never ended. But I think that the politics of the 1990s and mid-2000s cannot be called a full-blown Cold War.

Since the mid-1990s, captured in euphoria from the seemingly final victory, the West began to make mistakes. In Europe, most countries (except the northwestern ones) abandoned overripe economic reforms and approved a thoughtless enlargement of the EU and the introduction of the euro without single political leadership and called for a single foreign policy, thus tying the hands of the great European powers. This paved the way for the EU's current desperate crisis. The Americans, carried away by the temporary victory, believed in the obviously absurd idea that by starting capitalist reforms, China, an immense and deep-rooted civilization, would be reborn, democratized (that is, weakened), and would eventually follow the Western course. Americans began to understand their mistake only by the end of the 2000s, when they had already helped China gain economic power and development momentum.

In the 1990s, the West made another strategic miscalculation almost comparable in historical significance. The biggest part of the Russian elite and society sought integration with the West. But again, in euphoria and oblivion of history, this impulse was rejected. Instead, NATO's expansion began, followed by aggressions against Yugoslavia and Iraq, and finally by withdrawal from the ABM Treaty, which crushed those hopes completely.

Westernization quickly became marginal among the elites as Moscow sought to regain its military capability and great-power status, but this time as a country of the non-West. This was followed by its turn to the East, which further changed the balance in relations with Europe and within the Russian elite.

\section{THE CURRENT WAR}

In the mid-2000s, the West began to realize that its historical gains were turning into geostrategic and, subsequently, geoeconomic losses. 
And it unleashed rearguard battles. In the second half of the 2000s, it started cranking up pressure on Russia first and then on China, which was not so strong at first (due to the deep economic interdependence), but eventually increasingly hard.

The next major strategic mistake was that Russia and China, which were already drawing closer to each other due to overlapping objective and natural interests, were pushed towards a de facto strategic union, and Moscow was prodded into assuming not a non-Western, but an anti-Western political, geopolitical and economic orientation. The ideas of the last major American thinkers and strategists, Henry Kissinger and Zbigniew Brzezinski, about the usefulness of creating a Pacific community based on a U.S.-China condominium were discarded. Faced with growing pressure from the east (the United States), China headed west (Belt and Road) economically and politically, started to deepen its strategic partnership with Russia, and focused on the domestic market ("dual circulation" policy). Beijing's reorientation, with Moscow going eastward and Turkey turning away from the West, laid the groundwork for the political and economic recovery of Eurasia.

In the middle of the 2000s, Russia began strengthening its militarypolitical potential, inexpensively but very effectively, and by the end of the following decade apparently cut the ground from under the military foundation of the centuries-old dominance held by Europe and the West. This loss is the fundamental cause of the new round of the Cold War. As a result, the West is forced to go from expanding back to reducing the sphere of its dominance and control, and its external resource base.

Post-Soviet Russia did not seek to undermine the foundations of the West's dominance, but only wanted to ensure its own security and sovereignty, and stop the expansion, which began in the 1990s, into regions which it considers critical to its security. This policy also ensured greater freedom for most countries from the prior Western dominance that came as a concomitant effect.

Russia is demonized and accused of all sins. The vast majority of these accusations (not all, we are not angels after all) are evil 
nonsense. But there is some truth to it too-we did shatter the basis of the world order in which the West dominated and reaped hefty dividends. The current round of the Cold War, just like all the previous waves of intense rivalry between nations, means the West's struggle against redistribution of economic, human, and natural resources that does not benefit it.

Until relatively recently, the ideological element in this round of the Cold War was weaker than in the first two. Russia, China, and the other "new" were habitually accused (and still are accused) of authoritarianism, and China was even condemned for communist totalitarianism, although Western democracies (or rather, this type of management by the oligarchy, relatively comfortable for the majority) are crumbling all by themselves. This loss is due to entropy, relaxation after success, and degradation of the ruling elites, which is inevitable in democracy (elected are not the best, but convenient and like-minded). This is how democracies ceased to exist in the past, faced with external challenges and/or the inability of the ruling circles to ensure effective governance. I have written about this many times. ${ }^{1}$

Modern Western democracies, apparently, are not imperishable either. Democracies die to rise again one day, as always, in a different way and, possibly, in other regions. But the process of dying is extremely painful.

This, of course, does not mean that any kind of authoritarianism, let alone totalitarianism, is more effective than democracy. There are more than enough examples of failed authoritarian political systems. Russia has yet to prove that its modern political regime is indeed modernizing authoritarianism.

To justify increasingly harsh counterattacks, at the beginning of the century, the West came up with a concept of confrontation between authoritarian capitalism and democratic capitalism. This ideological component is still there. In recent years, it has been inertly complemented with the need to protect liberal values-democracy itself, human rights, the rule of law, and political pluralism. But the

See, for example, S. Karaganov. How to Win the Cold War. Rossiya v globalnoi politike, 5 , 2018. Available at: https://globalaffairs.ru/articles/kak-pobedit-v-holodnoj-vojne-2/ 
complex crisis within the West makes such arguments less convincing. Elections often turn into a farce, and late Soviet-era like-mindedness is forced upon people instead of ideological pluralism. The rights and interests of the majority, dissatisfied with its deteriorating situation, are pushed into the background for the sake of the rights of minorities or individuals.

So far, the ideological component has been playing a purely instrumental role in the new round of the Cold War, covering up the struggle for geoeconomic and geopolitical resources. The nonWest (Russia and China) is barely involved in this ideological battle. Accusations of "undermining democracies" are ridiculous. But it is very likely that this artificially induced confrontation between "democracy and authoritarianism" can be exacerbated by a much more powerful ideological component.

The erosion of basic human values is accelerating due to a number of objective cultural reasons and partially conscious policies pursued by the transnational (liberal) ruling circles of the United States and many European countries, which are losing their positions. Hence all manifestations of LGBTisms, multisexuality and ultrafeminism; denial of history, roots, and faith; and support for black racism, including its anti-Christianity and anti-Semitism. The list also includes democracy as a religion and not simply as a way of governing, and it can go on and on.

All these trends caricaturally resemble the practices of Soviet communism which also fought religion and faith, rewrote history, destroyed monuments, hoped that the family would be swept away and replaced by communization, and persecuted dissidents.

If the majority in Western countries does not stop this evolution (so far resistance is fairly weak), we may face a new, deeper ideological confrontation than the "communism-capitalism" or "democracyauthoritarianism" dichotomy. New pseudo ideologies, in fact, lead to the denial of human in humans.

We have to decide whether we should only fence ourselves off from this ideological epidemic or go on the offensive and try to lead the vast majority of humanity, including in countries that are seriously affected 
by these moral and ethical viruses. If an offensive strategy is chosen, it will further aggravate the confrontation. But it can also become a strong trump card in it, or at least an instrument of political deterrence to prevent its escalation.

\section{THE STRATEGY OF VICTORY}

So, the first round of the Cold War ended with a hot war, the second one with the defeat of Communism and the USSR. What are the chances in the current round unleashed against China and Russia? Let us count the resources. As a result of the Soviet Union's collapse, we have lost a significant part of the territory and population. Unsuccessful reforms have caused significant damage to the meritocratic elite, human capital, science, and high technology. The western security buffer has shrunk. The loss of global influence and the empire was a painful blow to many.

After a rapid growth in the 2000s, the economy has been stagnating, reducing somewhat the base of international influence. But most importantly, in the long run this is fraught with erosion of internal stability and loss of active public support for the authorities. The country's fundamental weakness is that it has no future-oriented ideology that would replace the bygone ones: the dead communist one, and the ideas of "returning" to Europe in the 1990s, "rising from knees" in the 2000s, and regaining the status of a first-class great power in the 2010s. Great nations collapse without such ideologies or after their loss. The ruling circles' decision to avoid the long-overdue "new Russian idea" that would unite the majority is quite puzzling. Highquality technocracy is necessary, but it will not secure a victory in the fight for the future. In the initial stages of the previous Cold War, the country had an idea, albeit a communist one, and a growing economy.

Yet there are a few positive aspects, as well. One had to pay for greatness. The price the Soviet Union had to pay for supporting the Third World countries of "socialist orientation," vassals in Eastern Europe and former Soviet republics, and the giant military machine was enormous. Before the defeat of 1990-1991, we were opposed by the Western civilization, which had just started losing, but was still powerful. Now it is falling apart politically and morally, and weakening 
economically (although, its accumulated economic, military, cultural, and information potential, called into play through sanctions and information warfare, is, in fact, still quite strong).

The political systems of most countries that have decided to challenge us and China are not adapted to a long and fierce confrontation. If we were opposed by the West ruled by more authoritarian and effective governments, the situation could be much more complicated. Authoritarian trends in the West will inevitably increase, just as everywhere else (with the pandemic already actively used for such a transition). But changing the political systems established over the past half-century will be painful and will take decades.

At the end of the previous Cold War, the intellectual state of the West was its strong trump card. Now the situation has changed dramatically. The West is in turmoil and no longer sets the trend. This is another reason for its panic, hostility, and desire to shut itself off from others. In the past, it was the Soviet Union that kept itself secluded from the world, while the West legitimately bragged about its openness to attract others. Another startling analogy with the Soviet Union-the insane deployment of NATO ground forces to Afghanistan and their predictable defeat after almost twenty years of fighting-looks like a farce.

We are not too well-off, but there is no shortage of everything like that we had in the past (which, apart from the decline of the communist idea, was the most important reason for the collapse). Russia has rebuilt its military machine-a first-class resource in a world of growing chaos and fierce competition (in the gold-sword dichotomy, the latter now prevails again) - for a small fraction of the previous price. It is another matter that it must be a special kind of sword. But with the latest generation of weapons, we have shown that we can lead wherever necessary at small cost. By rebalancing economic ties towards the East and reducing overwhelming economic dependence on the West that began fifteen years ago we get more room for maneuver.

Any patriot of our country cannot but mourn over the loss of ancestral lands. But most of these territories devoured Russia's resources. Now these territories supply us with a cheap workforce. Without it, the demographic decline that began in Soviet times would 
be much more painful. Trade is carried out at market, rather than subsidized, prices. This is one of the reasons why almost all former Soviet republics have become poor relatively sharply. The problem of Ukraine, created largely by our inaction in the past, remains, but the country is moving rapidly towards total insolvency. Assistance to developing countries is relatively minuscule. But what is most important is that we have kept Siberia-a key basis for development in the years to come.

A significant factor in calculating the balance of power is the decreasing share of the West in world GNP and the growing independence of the non-West, which provides more room for geoeconomic and geopolitical maneuvering. Russia has yet another important advantage-the experience of defeat in the previous Cold War and the absence of illusions and ideological blinders. So far we have avoided repeating Soviet mistakes: imperial over-involvement and copying a richer opponent's actions in the military field, and have abandoned the weird concept of necessary numeric equality (parity) in armaments.

Our most important advantage is that the majority of Russians and the Russian elite believe in their moral rightness. There was no such feeling in late Soviet society. This became one of the main reasons for the disintegration of the country. It is necessary to support this feeling with a forward-looking strategy and ideology, and get out of the economic stagnation that saps our spirit and vigor.

A fundamental change in Russia's geopolitical position occurred due to the transformation of China from an enemy into a friendly state, almost an ally. It is the most important external resource for development and saving money by reducing military expenditures. China is rebuilding its armed forces and redirecting its military strategy from land to sea. Beijing is not going to threaten us yet. A strong China is drawing off more and more U.S. military-political resources. Russia is doing the same for China. Russia is a strategic pillar in the military-political sphere and a safe source of the most critical natural resources for China.

History has drawn us to each other. And this is a huge gain in the current situation. It is necessary not only to deepen cooperation and 
advance it to the level of an informal union in the next decade, but also plan our China policy for the decades to follow, when uncontested good-neighborliness may have to be supplemented with stronger elements of balancing if China gets the better of the United States (which it has more chances to do) and suffers imperial dizziness from success. At this point, Beijing's relative defeat does not seem likely, but if it happens, Russia will have to rebalance its policy in its favor. The West must not be allowed to take the upper hand. It has already shown what it is capable of when it thinks it is winning-a series of aggressive acts and color revolutions that have plunged countries and entire regions into chaos and poverty.

We should assess the possibility that if the United States suffers a relative defeat, it may in a decade's time opt for a condominium with China proposed by Kissinger and Brzezinski. I suspect that those who decided to launch another Cold War against us, China, and the other "new" have already lost faith in their own rightness. In face-to-face debates, now quite rare, with Western colleagues, I simply told them more than once: "Stop lying." And they did. We Soviets used to be so shy. But this does not mean, however, that our opponents will give up quickly. They are trying to consolidate for the time being.

I will not name the steps that I think need to be taken in order to effectively develop and strengthen our positions in the world. I have written about this more than once in my articles over the last few years. ${ }^{2}$ I will only summarize the reflections described above.

We have a good chance of winning this Cold War. But the struggle will require us to commit a lot of national effort and work out a forward-looking ideology. It should not just rely on life-giving traditions but should lead into the future. Its contours are quite obvious. My colleagues and I have repeatedly described them. ${ }^{3}$ Many other thinking Russians have also come up with fruitful ideas.

\footnotetext{
2 See, for example, S. Karaganov. New Ideas for Ourselves and the World. Rossiya v globalnoi politike, 2, 2020. Available at: https://globalaffairs.ru/articles/novye-idei-dlya-sebya-i-mira/.

See, for example, S. Karaganov, D. Suslov, Ye. Primakov, I Makarov, L. Popovich. Protecting Peace, Earth, the Freedom of Choice for All Countries: New Ideas for Russia's Foreign Policy. Rossiya v globalnoi politike, 22 April, 2020. Available at: https://globalaffairs.ru/articles/zashhitamira-zemli-svobody/
} 
In order to create such an ideology and make it effective, it is necessary to maintain intellectual openness and pluralism. I think this can be done, although it will not be easy amid the ongoing confrontation. If such freedom is restricted, this will lead not only to a loss of competitive advantage, but also to inevitable mistakes in policies (the Soviet experience proves this). After the "win," history will continue, and new efforts will be needed to improve our country and find optimal balances in the world. We lost the previous round of the Cold War by taking on an overwhelming burden, among other things. Now Russia has an opportunity to become a balancer in the U.S.-China rivalry (more friendly towards China) and in the future system of Greater Eurasia.

In conclusion, I will repeat what I have said many times before: the risk of a new world war is extremely high. The world is balancing on the edge. An active peace policy is an imperative. If the line is crossed, history will end and there will be no fourth Cold War or anything else.

I was disgusted by the previous Cold War, which I lived through, and I am sick of the current one, but I would like analysts from future generations to be able to write similar articles, argue, and live on. 